\title{
Estimation of Twelve Bacopa Saponins in Bacopa monnieri Extracts and Formulations by High-Performance Liquid Chromatography ${ }^{1)}$
}

\author{
Papolu Bhargava Sriramachandra Murthy, Valivarti Raghava RaJu, Tummala Ramakrisana, \\ Mangu Srinivasa Chakravarthy, Katta Vijay Kumar, Sukala Kannababu, and \\ Gottumukkala Venkata SuBBARAJu*
}

Laila Research Centre, Unit I, Phase III, Jawahar Autonagar; Vijayawada-520 007, India.

Received January 10, 2006; accepted March 2, 2006

\begin{abstract}
A simple and sensitive reversed phase high performance liquid chromatographic (HPLC) method has been developed for the simultaneous determination of twelve bacopa saponins present in the extracts of the Indian Medicinal Plant, Bacopa monnieri. The separation was achieved on a reversed phase $C_{18}$ column (Luna $\left.C_{18}\right)$, $5 \mu \mathrm{m}$ by isocratic elution with $0.05 \mathrm{~m}$ sodium sulphate buffer $(\mathrm{pH} 2.3)$ and acetonitrile $(68.5: 31.5, \mathrm{v} / \mathrm{v})$ as the mobile phase at a flow rate of $1.0 \mathrm{ml} / \mathrm{min}$ with an operating temperature of $30{ }^{\circ} \mathrm{C}$. The method was validated for linearity, precision, intra- and inter-day precision and accuracy. Several Bacopa samples (plant materials, extracts and commercial formulations) were successfully analyzed. Major bacopasaponins were bacosides $A_{3}(3)$, bacopaside II (4), bacopaside I (5), bacopaside X (6), bacopasaponin C (7), bacopaside N2 (9) and the minor components were bacopasaponin F (1), bacopasaponin E (2), bacopaside N1 (8) bacopaside III (10), bacopaside IV (11) and bacopaside $V(12)$. The total saponin content in the samples, plant materials and extracts varied from 5.1 to $22.17 \%$ and 1.47 to $66.03 \mathrm{mg} /$ capsule or tablet in the commercial formulations.
\end{abstract}

Key words Bacopa monnieri; bacopasaponin; HPLC; formulation

Bacopa monnieri (Family: Scrophulariaceae) is a medicinal herb, found throughout the Indian subcontinent in wet, damp and marshy areas. ${ }^{2)}$ It is used in traditional Indian medicine, the Ayurveda, for the treatment of anxiety, and in improving intellect and memory for several centuries. ${ }^{3)}$ In addition to memory boosting activity, it is also claimed to be useful in the treatment of cardiac, respiratory ${ }^{4)}$ and neuropharmacological ${ }^{5)}$ disorders like insomnia, insanity, depression, psychosis, epilepsy and stress. It was reported to possess anti-inflammatory, analgesic, antipyretic, sedative ${ }^{6)}$ free radical scavenging and anti-lipid peroxidative activities ${ }^{7)}$ also.

The pharmacological properties ${ }^{8)}$ of Bacopa monnieri were studied extensively and the activities were attributed mainly due to the presence of characteristic saponins called as "bacosides." Bacosides are complex mixture of structurally closely related compounds, glycosides of either jujubogenin or pseudojujubogenin (Fig. 1). Bacosides have been found to offer protective role in the synaptic functions of the nerves in hippocampus. ${ }^{6}$ )

There are few methods reported in the literature for quantification of bacosides in plant extracts and formulations. Spectrophotometric methods ${ }^{9,10)}$ developed based on the hydrolysis of bacosides to an aglycone that has an absorption maximum at $278 \mathrm{~nm}$. The major limitation of this method is that it lacks specificity and has interference from other hydrolyzed compounds. A high performance thin-layer chromatographic (HPTLC) ${ }^{11)}$ method was developed for the estimation of bacoside $\mathrm{A}$ in Bacopa monnieri plant and its formulations. A few high performance liquid chromatographic (HPLC) ${ }^{12-16)}$ methods were also developed for the quantification of bacosides in Bacopa monnieri extracts and formulations. Ganzera et al. ${ }^{15)}$ reported the method for quantification of six saponins using gradient HPLC with PDA detector, but one of the major peaks was not completely characterized. Deepak et al. $^{16)}$ determined bacoside A which contains 4 compounds by HPLC, but did not consider bacoside B. In another report, bacosides were estimated by HPLC, coupled NMR, MS and bioassay methods described. ${ }^{14)}$

As the number of aged people suffering from cognitive problems increases the memory boosters have gained immense importance and there is an urgent need to develop sensitive and reliable quality control techniques to establish the authenticity and purity of memory boosting formulations. The value of the method increases with the estimation of all the characteristic compounds present in the extracts because the major components could be present in several closely related species. In the present study, a simple reversed phase HPLC method was developed and validated for separation and simultaneous quantification of all the 12 bacopa saponins in Bacopa monnieri plant, extracts and commercial formulations.

\section{Experimental}

Materials Compounds $\mathbf{1} \mathbf{- 1 2}$ were kindly provided by phytochemistry division of Laila Research Centre Vijayawada, India. Identity and purity $(>95 \%)$ of the isolated compounds were confirmed by chromatographic (TLC, HPLC) and spectral (IR, Mass and NMR) data. ${ }^{17-24)}$ Bacopa monnieri plant materials, extracts analyzed in this study were supplied by $\mathrm{M} / \mathrm{s}$ Laila Impex, Vijayawada, India and commercial formulations containing $\mathrm{Ba}$ copa monnieri were procured from the local market and Australia. Methanol and acetonitrile (HPLC grade), sodium sulphate and sulphuric acid (analytical grade) were purchased from Qualigens (Mumbai, India). Ultrapure water generated by the Barnstead nanopure system (Model D3750, U.S.A.) was used. Seventy percent $(\mathrm{v} / \mathrm{v})$ methanol in water was used as solvent for extraction of Bacopa monnieri plant materials. Sodium sulphate $(0.05 \mathrm{M})$ prepared in water and adjusted to $\mathrm{pH} 2.3$ with dilute sulphuric acid using Elico $\mathrm{pH}$ meter (model LI 120). Sulphate buffer $(\mathrm{pH} 2.3)$ and acetonitrile $(68.5: 31.5, \mathrm{v} / \mathrm{v})$ was used as mobile phase. Sulphate buffer $(\mathrm{pH} 2.3)$ and acetonitrile $(50: 50, \mathrm{v} / \mathrm{v})$ were used as a medium for preparation of extracts and commercial formulations. All solutions were filtered through $0.45 \mu \mathrm{m}$ pore size membrane filter using a Millipore Swinnex type filtration unit.

Sample Preparation. Bacopa monnieri Plant Material One to five grams of Bacopa monnieri powdered plant material was weighed into a $100 \mathrm{ml}$ round bottom flask, added about $30 \mathrm{ml}$ of $70 \%(\mathrm{v} / \mathrm{v})$ methanol and refluxed on a water bath for $30 \mathrm{~min}$. Filtered and the extraction was repeated twice $(2 \times 30 \mathrm{ml})$ with $70 \%(\mathrm{v} / \mathrm{v})$ methanol, combined all the alcoholic frac- 
<smiles>CC(C)=CC1C[C@](C)(O)C2OCC3(O1)C2CCC1[C@@]2(C)CC[C@H](O)C(C)(C)C2CC[C@@]13C</smiles>

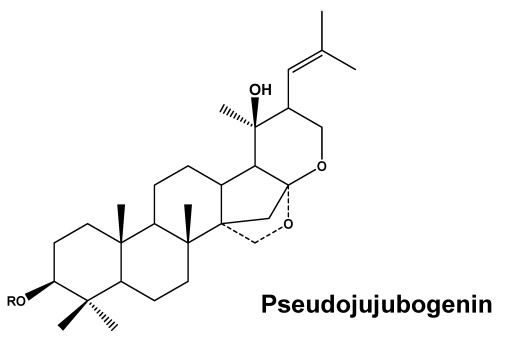

Fig. 1. Structures of Compounds $\mathbf{1}-\mathbf{1 2}$

\begin{tabular}{|c|c|c|}
\hline Compound & $\mathbf{R}$ & $\mathbf{R}_{1}$ \\
\hline Bacopasaponin F (1) & $\begin{array}{l}{[\beta \text {-D-glucopyranosyl- }(1 \rightarrow 3)-\{\alpha-L-\text {-arabinofuranosyl- }} \\
(1 \rightarrow 2)\}-\beta \text {-D-glucopyranosyl] }\end{array}$ & $(\alpha-L-$-arabinopyranosyl) \\
\hline Bacopasaponin E (2) & 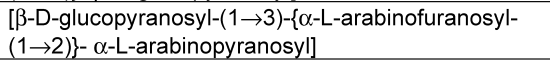 & ( $\alpha$-L-arabinopyranosyl) \\
\hline Bacoside $A_{3}(3)$ & 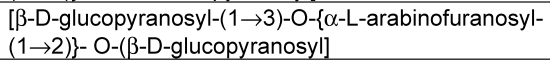 & $\mathrm{H}$ \\
\hline Bacopaside X (6) & $\begin{array}{l}{[\alpha-L-a r a b i n o f u r a n o s y l-(1 \rightarrow 2)-\{\beta \text {-D-glucopyranosil- }} \\
(1 \rightarrow 3)\}-\alpha \text {-L-arabinopyranosyl] }\end{array}$ & $\mathrm{H}$ \\
\hline Bacopaside N1 (8) & [ $\beta$-D-glucopyranosyl-(1 $\rightarrow 3)-\beta$-D-glucopyranosyl] & $\mathrm{H}$ \\
\hline Bacopaside IV (11) & {$[\beta$-D-glucopyranosyl-(1 $\rightarrow 3)$ - $\alpha$-L-arabinopyranosyl] } & $\mathrm{H}$ \\
\hline
\end{tabular}

\begin{tabular}{|c|c|}
\hline Compound & $\mathbf{R}$ \\
\hline Bacopaside II (4) & [ $\alpha$-L-arabinofuranosyl-( $1 \rightarrow 2)-\{\beta$-D-glucopyranosyl-( $1 \rightarrow 3)\}$ - $\beta$-D-glucopyranosyl] \\
\hline Bacopaside I (5) & $\begin{array}{l}\text { [ } \alpha \text {-L-arabinofuranosyl-(1 } \rightarrow 2)-\{6-0 \text {-sulphonyl- } \beta \text {-D-glucopyranosyl-( } 1 \rightarrow 3)\}-\alpha-L- \\
\text { arabinopyranosyl] }\end{array}$ \\
\hline Bacopasaponin C (7) & [ $\beta$-D-glucopyranosyl- $(1 \rightarrow 3)-\{\alpha-L-$-arabinofuranosyl- $(1 \rightarrow 2)\}-\alpha-L$-arabinopyranosyl] \\
\hline Bacopaside N2 (9) & 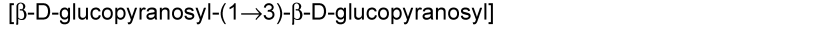 \\
\hline Bacopaside III (10) & [\{6-0-sulphonyl- $\beta-D-$-glucopyranosyl-( $1 \rightarrow 3)\}-\alpha-L-$-arabinopyranosyl] \\
\hline Bacopaside V (12) & [ $\beta$-D-glucopyranosyl-(1 $\rightarrow 3)-\alpha-L-$ arabinopyranosyl] \\
\hline
\end{tabular}

tions and made up to $100 \mathrm{ml}$ with $70 \%(\mathrm{v} / \mathrm{v})$ methanol and filtered through $0.45 \mu \mathrm{m}$ membrane filter.

Bacopa monnieri Extracts Five hundred milligrams of the sample was dissolved in a medium of sodium sulphate $(0.05 \mathrm{M})$ buffer $\mathrm{pH} 2.3$ and acetonitrile $(50: 50, \mathrm{v} / \mathrm{v})$, sonicated for $10 \mathrm{~min}$, diluted to $100 \mathrm{ml}$ with the same medium and filtered through $0.45 \mu \mathrm{m}$ membrane filter.

Commercial Formulations The average weight of the capsule/tablet was determined by weighing 20 capsules/tablets. In case of capsules, hard gelatin shells were removed and finely powdered. Fifty milligrams of the finely powdered samples were dissolved in a medium of sodium sulphate $(0.05 \mathrm{M})$ buffer $\mathrm{pH} 2.3$ and acetonitrile $(50: 50, \mathrm{v} / \mathrm{v})$, sonicated for $10 \mathrm{~min}$ and made up to $10 \mathrm{ml}$ with the same medium and filtered through $0.45 \mu \mathrm{m}$ membrane filter.

Calibration Standard solutions containing $10 \mathrm{mg} / \mathrm{ml}$ of the standards, 1-12, in a medium of sodium sulphate $(0.05 \mathrm{M})$ buffer $\mathrm{pH} 2.3$ and acetonitrile $(50: 50, \mathrm{v} / \mathrm{v})$ (Stock solution). Six additional calibration levels were prepared by diluting stock solutions with the same medium in the range of $1.0-60.0 \mu \mathrm{g} / 20 \mu \mathrm{l}$ (Table 1). The standard curves were obtained using the peak areas of six different concentrations in six replicate assays and were expressed by the linear least square regression equation.

HPLC Instrumentation HPLC experiments were performed on a Shimadzu HPLC system equipped with Phenomenex Luna $\mathrm{C}_{18}, 5 \mu \mathrm{m}$ $(4.6 \times 250 \mathrm{~mm})$ column, LC10AT VP pumps, SCL-10AVP system controller, SIL-10 AD VP auto injector, SPD-M10 AVP photodiode array detector and class VP software was used.

Analytical Method In this method, the mobile phase was a mixture of $0.05 \mathrm{~m}$ sodium sulphate buffer $\mathrm{pH} 2.3$ and acetonitrile $(68.5: 31.5, \mathrm{v} / \mathrm{v})$ at flow rate of $1 \mathrm{ml} / \mathrm{min}$ and the column temperature was maintained at $30^{\circ} \mathrm{C}$. The detection wave length was set at $205 \mathrm{~nm}$. The injection volume was $20 \mu \mathrm{l}$. The chromatography system was equilibrated by the mobile phase The separation and quantification of the samples was conducted when the same retention time and peak areas of the repetitive injection of the standard solutions were obtained. The total run time was $75 \mathrm{~min}$.

Method Validation The specificity of the method was ascertained by analyzing the standards and the samples. The peaks for compounds $\mathbf{1} \mathbf{- 1 2}$ in the samples were confirmed by comparing the retention times of the peak with that of standards.

The linearity of the method was checked with standards $\mathbf{1} \mathbf{- 1 2}$ with the calibration curves in the range $1.0-60.0 \mu \mathrm{g} / 20 \mu \mathrm{l}$, using six different concentrations in six replicate assays. Limit of detection (LOD) and limit of quantification (LOQ) were obtained from the standard deviation $(\sigma)$ of the blank response $(n=6)$ and slope $(S)$ of the calibration curve using the formulae $3.3 \sigma / S$ and $10 \sigma / S$, respectively.

Accuracy was determined by spiking pre-analyzed sample with low, medium and high concentrations in the calibration range of the standard compounds 1-12 and analyzed by the proposed method. The experiment was conducted six times to check the recovery of the analyte at different levels in the formulations.

Precision (intra- and inter-day) of the assay was verified by analyzing samples PM-1, PM-2 and PM-3. Six assays were carried out on each sample on the same day and on different days. Repeatability was confirmed by relative standard deviation $(\mathrm{RSD} \%)$ of compounds $(\mathbf{1}-\mathbf{1 2})$, estimated in three samples.

\section{Results and Discussion}

A simple method was developed for the estimation of bacopasaponins 1-12 based on reversed phase HPLC separation combined with UV detection. An isocratic system was chosen to minimize the variations of the base line and also considering simplicity, precision and accuracy. The stability of the sample and standards $\mathbf{1}-\mathbf{1 2}$ were checked and found to be stable for $48 \mathrm{~h}$. An extraction procedure for plant materials was evaluated by extracting the plant material (PM-1) with $3 \times 30 \mathrm{ml}$ of $70 \%$ methanol, which is sufficient for complete extraction of bacopa saponins $\mathbf{1}-\mathbf{1 2}$.

Major saponins found in Bacopa monnieri are derivatives of two aglycones, jujubogenin and pseudojujubogenin (Fig. 1). The saponins, in two groups, differ only in their sugar moieties. Bacopasaponins possess a weak chromophore. Separation of compounds $\mathbf{1}-\mathbf{1 2}$ was difficult and required a careful assessment of all separation parameters like stationary phase and elution conditions.

HPLC columns differing in stationary phase, pore size were initially screened for their potential to resolve the compounds 1-12. Special attention was paid to separation efficiency, peak shape and separation time. Best results were obtained with Luna $\mathrm{C}_{18}$ column $5 \mu \mathrm{m}$ particle size, $250 \mathrm{~mm}$ length and $4.6 \mathrm{~mm}$ i.d (Phenomenex) sodium sulphate $(0.05 \mathrm{~m})$ buffer $\mathrm{pH} 2.3$ and acetonitrile $(68.5: 31.5$, v/v) was used as mobile phase with $1 \mathrm{ml} / \mathrm{min}$ flow rate enabling the base line separation of all compounds within $75 \mathrm{~min}$. All the separations were performed at $30^{\circ} \mathrm{C}$. Absorption measurement at $205 \mathrm{~nm}$ was selected and the compounds $\mathbf{1}-\mathbf{1 2}$ were effectively detected (Fig. 2).

Validation of the Assay Method Method for the quanti- 
Table 1. Calibration, Linearity, LOD and LOQ Data for the Standard Compounds $\mathbf{1}-\mathbf{1 2}$

\begin{tabular}{|c|c|c|c|c|c|c|}
\hline Compound & $\begin{array}{l}\text { Retention time } \\
\qquad(\mathrm{min})\end{array}$ & $\begin{array}{l}\text { Linearity range } \\
\qquad(\mu \mathrm{g} / 20 \mu \mathrm{l})\end{array}$ & Regression equation & $\begin{array}{l}\text { Correlation } \\
\text { coefficient }\end{array}$ & $\begin{array}{l}\text { Limit of detection } \\
(\mathrm{LOD})(\mu \mathrm{g} / 20 \mu \mathrm{l})\end{array}$ & $\begin{array}{l}\text { Limit of quantification } \\
\quad(\mathrm{LOQ})(\mu \mathrm{g} / 20 \mu \mathrm{l})\end{array}$ \\
\hline 1 & $6.2 \pm 0.3$ & $20.0-60.0$ & $y=147.10 x+72.46 \times 10^{4}$ & 0.9973 & 0.022 & 0.068 \\
\hline 2 & $7.9 \pm 0.4$ & $20.0-60.0$ & $y=152.32 x+50.29 \times 10^{4}$ & 0.9984 & 0.022 & 0.066 \\
\hline 3 & $32.9 \pm 0.4$ & $2.5-15.0$ & $y=80.87 x+10.99 \times 10^{3}$ & 0.9995 & 0.040 & 0.124 \\
\hline 4 & $35.4 \pm 0.3$ & $2.0-12.0$ & $y=249.09 x-35.14 \times 10^{3}$ & 0.9989 & 0.013 & 0.040 \\
\hline 5 & $38.4 \pm 0.4$ & $2.0-12.0$ & $y=253.08 x-17.65 \times 10^{3}$ & 0.9997 & 0.013 & 0.039 \\
\hline 6 & $42.0 \pm 0.3$ & $1.0-4.0$ & $y=120.84 x+19.31 \times 10^{3}$ & 0.9939 & 0.027 & 0.083 \\
\hline 7 & $46.8 \pm 0.3$ & $2.5-15.0$ & $y=280.81 x-60.20 \times 10^{3}$ & 0.9997 & 0.012 & 0.036 \\
\hline 8 & $51.2 \pm 0.3$ & $2.0-12.0$ & $y=239.65 x-35.87 \times 10^{3}$ & 0.9999 & 0.014 & 0.042 \\
\hline 9 & $52.6 \pm 0.4$ & $2.5-25.0$ & $y=236.71 x+62.52 \times 10^{3}$ & 0.9998 & 0.014 & 0.042 \\
\hline 10 & $57.5 \pm 0.3$ & $1.5-6.5$ & $y=149.91 x-53.89 \times 10^{3}$ & 0.9961 & 0.022 & 0.067 \\
\hline 11 & $61.9 \pm 0.4$ & $1.0-4.0$ & $y=209.53 x-35.28 \times 10^{3}$ & 0.9944 & 0.016 & 0.048 \\
\hline 12 & $67.3 \pm 0.2$ & $1.5-5.0$ & $y=346.22 x-33.97 \times 10^{3}$ & 0.9980 & 0.010 & 0.030 \\
\hline
\end{tabular}

Where $y=$ peak area, $x=$ concentration of the compound $\mu \mathrm{g} / 20 \mu \mathrm{l}$.
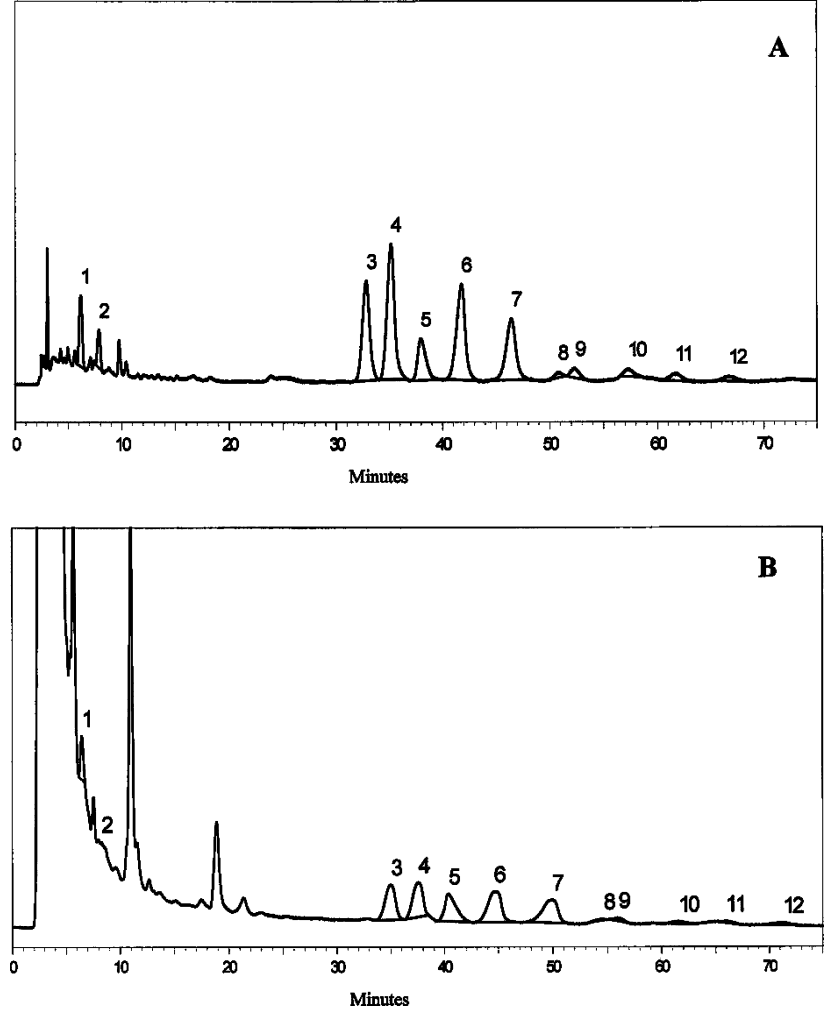

Fig. 2. HPLC Chromatograms: (A) Bacopa monnieri Extract (EM-1), (B) Ginko Brahmi Tablets (FM-6 Contains Bacopa monnieri and Ginko biloba Extracts)

Peak assignment according to Fig. 1.

tative analysis of compounds $\mathbf{1}-\mathbf{1 2}$ was validated with regard to its specificity, linearity, accuracy and precision by utilizing the ICH guidelines. ${ }^{25)}$ The specificity of the method was confirmed by reliability of compound peaks corresponding to compounds $\mathbf{1}-\mathbf{1 2}$ in the sample. Bacopa monnieri sample was spiked with the compounds $\mathbf{1}-\mathbf{1 2}$, individually, were separated by mobile phase sodium sulphate $(0.05 \mathrm{M})$ buffer $\mathrm{pH} 2.3$ and acetonitrile $(68.5: 31.5, \mathrm{v} / \mathrm{v})$. The peak areas of the compounds $\mathbf{1 - 1 2}$ in the sample were changed consistently with their corresponding standards. The study confirmed the stable retention times of the compounds $\mathbf{1}-\mathbf{1 2}$ in the samples were comparable with retention times of standard compounds $\mathbf{1}-\mathbf{1 2}$ with \pm 0.2 to $\pm 0.3 \mathrm{~min}$ variation
Table 2. Recovery Studies $(n=6)$

\begin{tabular}{|c|c|c|c|}
\hline Compound & $\begin{array}{l}\text { Amount of } \\
\text { compound } \\
\text { added }(\mathrm{mg})\end{array}$ & $\begin{array}{l}\text { Amount of } \\
\text { compound recovered } \\
(\mathrm{mg} \pm \text { S.D. })\end{array}$ & \% Recovery \\
\hline \multirow[t]{3}{*}{ Bacopasaponin F (1) } & 0.8240 & $0.8096 \pm 0.0029$ & 98.25 \\
\hline & 1.6480 & $1.6220 \pm 0.0089$ & 98.42 \\
\hline & 2.4720 & $2.4446 \pm 0.0079$ & 98.89 \\
\hline \multirow[t]{3}{*}{ Bacopasaponin E (2) } & 0.9025 & $0.8994 \pm 0.0026$ & 99.65 \\
\hline & 1.8050 & $1.8031 \pm 0.0049$ & 99.89 \\
\hline & 2.7075 & $2.7156 \pm 0.0120$ & 100.29 \\
\hline \multirow[t]{3}{*}{ Bacoside $\mathrm{A}_{3}(\mathbf{3})$} & 1.2151 & $1.1940 \pm 0.0170$ & 98.26 \\
\hline & 2.4303 & $2.4372 \pm 0.0081$ & 100.28 \\
\hline & 3.6455 & $3.6768 \pm 0.0260$ & 100.86 \\
\hline \multirow[t]{3}{*}{ Bacopaside II (4) } & 1.2075 & $1.2100 \pm 0.0053$ & 100.20 \\
\hline & 2.4150 & $2.4284 \pm 0.0076$ & 100.55 \\
\hline & 3.6225 & $3.6319 \pm 0.0096$ & 100.25 \\
\hline \multirow[t]{3}{*}{ Bacopaside I (5) } & 1.5023 & $1.4800 \pm 0.0035$ & 98.52 \\
\hline & 3.0046 & $2.9836 \pm 0.0074$ & 99.30 \\
\hline & 4.5068 & $4.5271 \pm 0.0075$ & 100.45 \\
\hline Bacopaside X (6) & 2.7150 & $2.6756 \pm 0.0051$ & 98.55 \\
\hline \multirow[t]{3}{*}{ Bacopasaponin C (7) } & 0.9876 & $0.9847 \pm 0.0052$ & 99.70 \\
\hline & 1.9751 & $1.9523 \pm 0.0039$ & 98.84 \\
\hline & 2.9627 & $2.8766 \pm 0.0760$ & 97.10 \\
\hline \multirow[t]{3}{*}{ Bacopaside N1 (8) } & 0.9591 & $0.9049 \pm 0.0061$ & 94.35 \\
\hline & 1.9182 & $1.8043 \pm 0.0102$ & 94.06 \\
\hline & 2.8773 & $2.7075 \pm 0.0310$ & 94.10 \\
\hline \multirow[t]{3}{*}{ Bacopaside N2 (9) } & 1.0189 & $1.0193 \pm 0.0032$ & 100.04 \\
\hline & 2.0378 & $1.9979 \pm 0.0180$ & 98.04 \\
\hline & 3.0568 & $3.0244 \pm 0.0150$ & 98.94 \\
\hline Bacopaside III (10) & 3.5250 & $3.4879 \pm 0.0105$ & 98.95 \\
\hline Bacopaside IV (11) & 2.0150 & $1.9743 \pm 0.0208$ & 97.98 \\
\hline \multirow[t]{3}{*}{ Bacopaside V (12) } & 0.1846 & $0.1842 \pm 0.0010$ & 99.78 \\
\hline & 0.3691 & $0.3662 \pm 0.0010$ & 99.21 \\
\hline & 0.5537 & $0.5503 \pm 0.0071$ & 99.38 \\
\hline
\end{tabular}

(Table 1)

The linearity of the method was checked with standards corresponding to $\mathbf{1} \mathbf{- 1 2}$ with the calibration curves in the concentration range $1.0-60.0 \mu \mathrm{g} / 20 \mu \mathrm{l}$. The regression equation and correlation coefficients were obtained with six replicate analyses for each concentration. The results of linearity data was reported in Table 1 shows that the correlation coefficient of the equations were $>0.99$ and the 12 calibration curves yielded straight lines in a wide range.

The limit of detection (LOD) of compounds $\mathbf{1} \mathbf{- 1 2}$ were in the range of $0.010-0.040 \mu \mathrm{g}$ per injection and the limit of quantification (LOQ) of $\mathbf{1}-\mathbf{1 2}$ were in the range 0.030 
$0.124 \mu \mathrm{g}$ per injection (Table 1).

Accuracy of the analytical method was determined by spiking sample with known amounts of $\mathbf{1 - 1 2}$ at three concentration levels. Due to the low amounts of standard compounds 6, 10 and 11 available, recovery was determined at middle concentration level only. The samples were analyzed under optimized conditions and the recovery rates were observed in the range 94.06 to $100.86 \%$ (Table 2).

The precision of the method was validated by both intraand inter-day variations. To determine intra-day variation six assays were carried out on same sample at different times during the day and inter-day variation was determined by analyzing on next day. Precision of the assay was verified by analyzing samples PM-1, PM-2 and PM-3 and found the percent relative standard deviation ( $\mathrm{RSD} \%$ ) of intra- and inter- day variation was in the range of $0.11-8.50 \%$ for all compounds (Table 3 ).

Application of the Method The method developed was applied to analyze three different Bacopa monnieri plant materials (PM), two different extracts (EM) and six different commercial formulations (FM), which were procured from domestic market and Australia. The results presented in Table 4 reveal that the compounds Bacoside $A_{3}$ (3), Bacopaside II (4), Bacopaside I (5), Bacopaside X (6) and Bacopasaponin $C$ (7) were major components and the remaining were minor, but, in quantifiable amounts in Bacopa monnieri plant materials (PM) and total saponins are in the range $5.1-6.0 \%$. Compounds 3-12 were the major peaks whereas Bacopasaponin F (1) and Bacopasaponin E (2) have been detected as minor components in Bacopa monnieri ex-

Table 3. Intra- and Inter-day Precision of Samples (PM-1, PM-2 and PM-3)

\begin{tabular}{|c|c|c|c|c|c|c|}
\hline \multirow{2}{*}{ Compound } & \multicolumn{3}{|c|}{ Intra-day $(n=6)$} & \multicolumn{3}{|c|}{ Inter-day $(n=6)$} \\
\hline & PM-1 & PM-2 & PM-3 & PM-1 & PM-2 & PM-3 \\
\hline 1 & $0.018(3.51)$ & $0.040(1.58)$ & $0.035(2.72)$ & $0.019(2.63)$ & $0.044(2.62)$ & $0.037(1.46)$ \\
\hline 2 & $0.007(8.50)$ & $0.010(7.66)$ & $0.015(5.44)$ & $0.006(6.62)$ & $0.011(5.17)$ & $0.016(5.21)$ \\
\hline 3 & $1.857(1.35)$ & $1.756(0.13)$ & $2.619(0.59)$ & $1.823(0.62)$ & $1.783(0.44)$ & $2.620(0.35)$ \\
\hline 4 & $1.545(0.78)$ & $0.777(0.29)$ & $0.834(0.15)$ & $1.551(0.24)$ & $0.783(0.35)$ & $0.827(0.50)$ \\
\hline 5 & $0.736(0.46)$ & $0.656(0.40)$ & $0.625(0.40)$ & $0.733(0.60)$ & $0.659(0.21)$ & $0.627(0.46)$ \\
\hline 6 & $0.978(2.29)$ & $1.015(0.14)$ & $1.016(0.11)$ & $0.988(0.68)$ & $1.021(0.52)$ & $1.532(0.21)$ \\
\hline 7 & $0.727(1.04)$ & $0.687(0.11)$ & $0.735(0.40)$ & $0.725(0.57)$ & $0.687(0.24)$ & $0.730(0.66)$ \\
\hline 8 & $0.004(0.00)$ & 0.034 (1.63) & $0.008(0.00)$ & $0.004(10.65)$ & $0.036(1.96)$ & $0.008(5.00)$ \\
\hline 9 & $0.039(4.60)$ & $0.029(2.78)$ & $0.017(2.99)$ & $0.036(5.56)$ & $0.030(1.85)$ & $0.017(3.72)$ \\
\hline 10 & $0.047(2.56)$ & $0.040(2.93)$ & $0.061(3.39)$ & $0.052(4.30)$ & $0.038(0.00)$ & $0.061(3.02)$ \\
\hline 11 & $0.048(3.85)$ & $0.033(3.63)$ & $0.031(0.00)$ & $0.048(4.27)$ & $0.034(0.00)$ & $0.030(5.58)$ \\
\hline 12 & $0.007(7.04)$ & $0.020(5.00)$ & $0.014(4.28)$ & $0.007(8.50)$ & $0.021(2.66)$ & $0.012(3.36)$ \\
\hline Total & 6.013 & 5.097 & 6.010 & 5.992 & 5.147 & 6.517 \\
\hline
\end{tabular}

Values in \% (g/100 g): relative standard deviations are given in parentheses.

Table 4. Estimation of Bacopa saponins $\mathbf{1} \mathbf{- 1 2}$ in Samples

\begin{tabular}{|c|c|c|c|c|c|c|c|c|c|c|c|c|c|}
\hline \multirow{2}{*}{ Sample } & \multicolumn{13}{|c|}{ Bacopasaponins } \\
\hline & 1 & 2 & 3 & 4 & 5 & 6 & 7 & 8 & 9 & 10 & 11 & 12 & Total \\
\hline PM-1 & $\begin{array}{l}0.018 \\
(3.51)\end{array}$ & $\begin{array}{l}0.007 \\
(8.50)\end{array}$ & $\begin{array}{c}1.857 \\
(1.35)\end{array}$ & $\begin{array}{l}1.545 \\
(0.78)\end{array}$ & $\begin{array}{l}0.736 \\
(2.29)\end{array}$ & $\begin{array}{l}0.978 \\
(2.29)\end{array}$ & $\begin{array}{l}0.727 \\
(1.04)\end{array}$ & $\begin{array}{l}0.004 \\
(0.00)\end{array}$ & $\begin{array}{l}0.039 \\
(4.60)\end{array}$ & $\begin{array}{l}0.047 \\
(2.56)\end{array}$ & $\begin{array}{l}0.048 \\
(3.85)\end{array}$ & $\begin{array}{l}0.007 \\
(7.04)\end{array}$ & $6.013^{a)}$ \\
\hline PM-2 & $\begin{array}{l}0.040 \\
(1.58)\end{array}$ & $\begin{array}{l}0.010 \\
(7.66)\end{array}$ & $\begin{array}{l}1.756 \\
(0.13)\end{array}$ & $\begin{array}{l}0.777 \\
(0.29)\end{array}$ & $\begin{array}{l}0.656 \\
(0.40)\end{array}$ & $\begin{array}{r}1.015 \\
(0.14)\end{array}$ & $\begin{array}{l}0.687 \\
(0.11)\end{array}$ & $\begin{array}{l}0.034 \\
(1.63)\end{array}$ & $\begin{array}{l}0.029 \\
(2.78)\end{array}$ & $\begin{array}{l}0.040 \\
(2.93)\end{array}$ & $\begin{array}{l}0.033 \\
(3.63)\end{array}$ & $\begin{array}{l}0.020 \\
(5.00)\end{array}$ & $5.097^{a)}$ \\
\hline PM-3 & $\begin{array}{l}0.035 \\
(2.72)\end{array}$ & $\begin{array}{l}0.015 \\
(5.44)\end{array}$ & $\begin{array}{l}2.619 \\
(0.59)\end{array}$ & $\begin{array}{l}0.834 \\
(0.15)\end{array}$ & $\begin{array}{l}0.625 \\
(0.40)\end{array}$ & $\begin{array}{r}1.016 \\
(0.11)\end{array}$ & $\begin{array}{l}0.735 \\
(0.40)\end{array}$ & $\begin{array}{l}0.008 \\
(0.00)\end{array}$ & $\begin{array}{l}0.017 \\
(2.99)\end{array}$ & $\begin{array}{l}0.061 \\
(3.39)\end{array}$ & $\begin{array}{l}0.031 \\
(0.00)\end{array}$ & $\begin{array}{l}0.014 \\
(4.28)\end{array}$ & $6.010^{a)}$ \\
\hline EM-1 & $\begin{array}{l}0.227 \\
(8.19)\end{array}$ & $\begin{array}{l}0.073 \\
(7.83)\end{array}$ & $\begin{array}{l}5.163 \\
(1.18)\end{array}$ & $\begin{array}{l}1.620 \\
(0.62)\end{array}$ & $\begin{array}{l}1.757 \\
(1.74)\end{array}$ & $\begin{array}{l}3.300 \\
(1.60)\end{array}$ & $\begin{array}{l}2.133 \\
(1.08)\end{array}$ & $\begin{array}{l}0.753 \\
(4.06)\end{array}$ & $\begin{array}{l}2.177 \\
(3.91)\end{array}$ & $\begin{array}{l}1.847 \\
(0.83)\end{array}$ & $\begin{array}{l}1.617 \\
(3.41)\end{array}$ & $\begin{array}{l}1.500 \\
(5.81)\end{array}$ & $22.167^{a)}$ \\
\hline EM-2 & $\begin{array}{l}0.093 \\
(6.19)\end{array}$ & $\begin{array}{l}0.027 \\
(6.21)\end{array}$ & $\begin{array}{l}2.693 \\
(6.18)\end{array}$ & $\begin{array}{l}1.647 \\
(0.75)\end{array}$ & $\begin{array}{l}2.293 \\
(1.33)\end{array}$ & $\begin{array}{l}3.360 \\
(1.81)\end{array}$ & $\begin{array}{l}2.467 \\
(1.87)\end{array}$ & $\begin{array}{l}0.243 \\
(4.23)\end{array}$ & $\begin{array}{l}0.777 \\
(1.49)\end{array}$ & $\begin{array}{l}0.670 \\
(5.17)\end{array}$ & $\begin{array}{l}0.410 \\
(8.19)\end{array}$ & $\begin{array}{l}0.667 \\
(3.53)\end{array}$ & $15.347^{a)}$ \\
\hline FM-1 & Nil & Nil & Nil & $\begin{array}{l}0.250 \\
(2.40)\end{array}$ & $\begin{array}{l}0.412 \\
(0.17)\end{array}$ & $\begin{array}{l}0.282 \\
(2.46)\end{array}$ & $\begin{array}{l}0.181 \\
(1.65)\end{array}$ & $\begin{array}{l}0.038 \\
(1.50)\end{array}$ & $\begin{array}{l}0.106 \\
(5.71)\end{array}$ & $\begin{array}{l}0.200 \\
(3.07)\end{array}$ & Nil & Nil & $1.469^{b)}$ \\
\hline FM-2 & $\begin{array}{l}0.380 \\
(1.22)\end{array}$ & $\begin{array}{l}0.104 \\
(0.91)\end{array}$ & $\begin{array}{c}1.830 \\
(1.23)\end{array}$ & $\begin{array}{l}0.273 \\
(1.54)\end{array}$ & $\begin{array}{l}0.603 \\
(1.64)\end{array}$ & $\begin{array}{l}0.691 \\
(7.91)\end{array}$ & $\begin{array}{l}0.684 \\
(0.96)\end{array}$ & $\begin{array}{l}0.353 \\
(0.54)\end{array}$ & $\begin{array}{l}0.046 \\
(6.63)\end{array}$ & $\begin{array}{l}0.273 \\
(5.18)\end{array}$ & Nil & Nil & $5.237^{b)}$ \\
\hline FM-3 & $\begin{array}{l}0.626 \\
(0.79)\end{array}$ & $\begin{array}{l}0.337 \\
(0.60)\end{array}$ & $\begin{array}{c}20.508 \\
(0.06)\end{array}$ & $\begin{array}{l}9.318 \\
(0.80)\end{array}$ & $\begin{array}{l}8.387 \\
(0.86)\end{array}$ & $\begin{array}{c}14.595 \\
(0.07)\end{array}$ & $\begin{array}{l}8.709 \\
(0.61)\end{array}$ & $\begin{array}{l}0.345 \\
(0.17)\end{array}$ & $\begin{array}{l}1.081 \\
(0.61)\end{array}$ & $\begin{array}{l}0.696 \\
(0.82)\end{array}$ & $\begin{array}{l}0.495 \\
(0.95)\end{array}$ & $\begin{array}{l}0.703 \\
(0.11)\end{array}$ & $65.800^{b)}$ \\
\hline FM-4 & $\begin{array}{l}0.797 \\
(0.54)\end{array}$ & $\begin{array}{l}0.367 \\
(1.45)\end{array}$ & $\begin{array}{l}8.524 \\
(0.15)\end{array}$ & $\begin{array}{l}4.282 \\
(0.38)\end{array}$ & $\begin{array}{l}5.561 \\
(0.25)\end{array}$ & $\begin{array}{l}5.699 \\
(1.38)\end{array}$ & $\begin{array}{l}4.680 \\
(0.42)\end{array}$ & $\begin{array}{l}0.644 \\
(0.72)\end{array}$ & $\begin{array}{l}2.220 \\
(0.76)\end{array}$ & $\begin{array}{l}1.877 \\
(1.01)\end{array}$ & $\begin{array}{l}1.102 \\
(0.69)\end{array}$ & $\begin{array}{l}0.635 \\
(2.75)\end{array}$ & $36.388^{b)}$ \\
\hline FM-5 & $\begin{array}{l}0.986 \\
(2.47)\end{array}$ & $\begin{array}{l}0.186 \\
(0.96)\end{array}$ & $\begin{array}{c}20.864 \\
(0.25)\end{array}$ & $\begin{array}{l}7.843 \\
(0.29)\end{array}$ & $\begin{array}{l}8.851 \\
(1.28)\end{array}$ & $\begin{array}{c}14.647 \\
(0.34)\end{array}$ & $\begin{array}{l}8.790 \\
(1.60)\end{array}$ & $\begin{array}{l}0.467 \\
(0.60)\end{array}$ & $\begin{array}{l}0.810 \\
(1.98)\end{array}$ & $\begin{array}{l}1.039 \\
(1.76)\end{array}$ & $\begin{array}{l}0.498 \\
(1.24)\end{array}$ & $\begin{array}{l}0.786 \\
(2.34)\end{array}$ & $65.767^{b)}$ \\
\hline FM-6 & $\begin{array}{l}3.617 \\
(1.02)\end{array}$ & $\begin{array}{l}0.069 \\
(2.83)\end{array}$ & $\begin{array}{c}20.775 \\
(0.17)\end{array}$ & $\begin{array}{l}8.119 \\
(1.05)\end{array}$ & $\begin{array}{l}7.976 \\
(0.50)\end{array}$ & $\begin{array}{c}14.080 \\
(0.55)\end{array}$ & $\begin{array}{l}8.548 \\
(1.07)\end{array}$ & $\begin{array}{l}0.060 \\
(3.51)\end{array}$ & $\begin{array}{l}0.721 \\
(0.24)\end{array}$ & $\begin{array}{l}0.581 \\
(1.36)\end{array}$ & $\begin{array}{l}0.517 \\
(1.82)\end{array}$ & $\begin{array}{l}0.964 \\
(1.61)\end{array}$ & $66.027^{b)}$ \\
\hline
\end{tabular}

PM: Bacopa monnieri plant materials; EM: Bacopa monnieri extracts; FM-1: Brahmi capsules, Himalaya Pure Herbs, India; FM-2: Stresswin capsules, Siddhayu Ayurvedic Research Foundation (P) Ltd., India; FM-3: Super Brahmi+Ginko capsules, Nutrilife Health and Fitness (NZ) Ltd., Newzealand; FM-4: Brahmi 6000 plus capsules, Carlson Health, Australia; FM-5: Mega Memory 3000 tablets, Totally Natural Products, Australia; FM-6: Ginko Brahmi Tablets, Blackmores Limited, Australia. Data represent the mean of six determinations; relative standard deviations are given in parentheses; $a$ ) expressed in $\mathrm{g} / 100 \mathrm{~g} ; b$ ) expressed in $\mathrm{mg} / \mathrm{capsule}$ or tablet. 
tracts (EM). Major part of the saponin content was contributed by compounds $\mathbf{3 - 1 0}$ in all commercial formulations analyzed. Bacopaside IV (11) and Bacopaside V (12) were not present in commercial formulations (FM-1 and FM-2) procured in the domestic market. The total saponin content of the formulations are in the range $1.47-66.03 \mathrm{mg}$ per capsule or tablet. The total saponin content was relatively less in formulations procured from domestic market (FM-1 and FM2) in comparison with formulations procured from Australia.

The presence of the herbal extracts of Withania somnifera, Nardostachys jatamansi, Ginko biloba, Panax ginseng and Capsicum annum, Vitamin B-Complex viz. thiamine $\mathrm{HCl}$, riboflavine, pyridoxine $\mathrm{HCl}$, niacinamide does not interfere in the estimation of bacosides $\mathbf{1 - 1 2}$ in commercial formulations. As such, the method may be applicable for polyherbal formulations also.

\section{Conclusions}

It was established from the pharmacological studies that bacosaponins were responsible for the biological activity of Bacopa monnieri. A simple reversed phase HPLC method has been developed for the simultaneous determination of all 12 bacopa saponins. The results demonstrate that the method developed was highly specific, accurate and precise and it could be used in the quality control of Bacopa monnieri extracts and formulations like tablets and capsules.

Acknowledgements The authors thank Sri G. Ganga Raju, Chairman, Laila group, Vijayawada, India for providing facilities and encouragement.

\section{References and Note}

1) Laila Impex Communication $\# 54$

2) Kapoor L. D., "Hand Book of Ayurvedic Medicinal Plants," CRC Press, Boca Raton, 1990.

3) Singh H. K., Dhawan B. N., Indian J. Pharmacol., 29, 359-365 (1997).
4) Nadkarni K. M., "The Indian Materia Medica," South Asia Books, Columbia MO, 1988.

5) Russo A., Borrelli F., Phytomedicine, 12, 305-317 (2005)

6) Kishore K., Singh M., Indian J. Exper. Biol., 43, 640 - 645 (2005).

7) Anbarasi K., Vani G., Balakrishna K., Desai C. S., Vascul. Pharmacol., 42, 57-61 (2005)

8) Deepak M., Amit A., Phytomedicine, 11, 264-268 (2004).

9) Pal R., Sarin J. P. S., Indian J. Pharm. Sci., 54, 17-18 (1992).

10) Singh H. K., Rastogi R. P., Srimal R. C., Dhawan B. N., Phytotherapy Res., 2, 70—74 (1998).

11) Shrikumar S., Sandip S., Ravi T. K., Umamaheswari M., Indian J. Pharm. Sci., 66, 132-135 (2004).

12) Pal R., Dwivedi A. K., Singh S., Kulshrestha D. K., Indian J. Pharm. Sci., 60, 328-329 (1998).

13) Gupta A. P., Madhur S., Gupta M. M., Sushil K. W., J. Med. Aromatic Plant. Sci., 20, 1052-1055 (1998).

14) Renukappa T., Roos G., Klaiber I., Vogler B., Kraus W., J. Chromatogr. A, 847, 109-116 (1999).

15) Ganzera M., Gampenrieder J., Pawar R. S., Khan I. A., Stuppner H., Anal. Chim. Acta, 516, 149-154 (2004).

16) Deepak M., Sangli G. K., Arun P. C., Amit A., Phytochem. Anal., 16, 24-29 (2005)

17) Mahato S. B., Garai S., Chakravarty A. K., Phytochemistry, 53, 711714 (2000).

18) Rastogi S., Pal R., Kulshreshtha D. K., Phytochemistry, 36, 133-137 (1994).

19) Chakravarty A. K., Sarkar T., Masuda K., Shiojima K., Nakane T., Kawahara N., Phytochemistry, 58, 553-556 (2001).

20) Higuchi R., Kubota S., Komri T., Kawasaki T., Pandey V. B., Singh J. P., Sahah A. H., Phytochemistry, 23, 2597-2600 (1984).

21) Garai S., Mahato S. B., Ohtami K., Yamasaki K., Phytochemistry, 42, 815 -820 (1996).

22) Sivaramakrishna C., Rao C. V., Trimurtulu G., Vanisri M., Subbaraju G. V., Phytochemistry, 66, 2719-2728 (2005).

23) Hou C. C., Lin S. J., Cheng J. Y., Hsu F. L., J. Nat. Prod., 65, 17591763 (2002).

24) Chakravarty A. K., Garai S., Masuda K., Nakane T., Kawahara N., Chem. Pharm. Bull., 51, 215-217 (2003).

25) ICH Topic Q2B, Validation of Analytical Procedures: Methodology, London, 1996. 